\title{
Community Behavior Patterns That Influence The Causes of Dengue Hemorrhagic Fever (DHF) in The Pondok Petir Elementary Region
}

\author{
Aulia Saputra \\ Public Health Faculty, Muhammadiyah University of Jakarta \\ K.H. Ahmad Dahlan St, Cireundeu, Ciputat South Jakarta, 151419 \\ E-mail: auliasaputra288@gmail.com
}

\begin{abstract}
Dengue Hemorrhagic Fever (DHF) is a disease caused by the bite of the Aedes Aegypti mosquito infected with one of the four types of dengue virus with clinical manifestations of fever, muscle aches, and/or joint pain accompanied by leukopenia, rash, lymphadenopathy, thrombocytopenia and hemorrhagic diathesis. In dengue hemorrhagic fever, plasma leakage occurs which is characterized by hemoconcentration (increased hematocrit) or fluid accumulation in body cavities (World Health Organization). Dengue Hemorrhagic Fever Penyakit (DHF) is still one of the main public health problems in Indonesia. The number of sufferers and the area of spread of DHF is increasing along with the increase in mobility and population density, especially in tropical and subtropical areas (Kemenkes RI, 2010). At the beginning of 2019, Dengue Hemorrhagic Fever (DHF) again increased in several areas, even becoming an Extraordinary Event (KLB) status. In January 2019 there were 15,132 DHF sufferers with 145 people dying in 34 provinces. This figure is twice as high as the figure at the end of January 2018 which recorded 6,167 DHF sufferers with 43 people dying. To find out the behavioral factors of DHF disease in the community in the Pondok Petir subdistrict area in 2020. Research Setting: According to data in 2019, Dengue Hemorrhagic Fever (DHF) has increased again in several areas, even becoming an Extraordinary Event (KLB) status. In January 2019 there were 15,132 DHF sufferers with 145 people dying in 34 provinces. This figure is twice as high as the figure at the end of January 2018 which recorded 6,167 DHF sufferers with 43 people dying. East Java, West Java, and DKI Jakarta are the three provinces that experienced an increase in the number of dengue cases compared to the previous year. This research uses the Simple Random Sampling technique. This study studied the incidence of dengue in children to adults (dependent variable), with respondent characteristics (age, history of dengue disease), counseling (knowledge), attitudes (family attitudes), and behavioral patterns (behavior of health workers, rarely monitoring larvae). mosquitoes, distribution of abate powder, fogging activities), and increasing community participation in dengue prevention (independent variable). To obtain the data, an in-depth interview and document review approach was conducted with the community at Pondok Petir. This research was conducted at Pondok Petir, South Tangerang in June 2021. The sub-categories in this study were DHF, Age, History of DHF, Knowledge, Family Attitude, Behavioral Patterns, Behavioral Patterns of Health Workers, Rarely Monitoring Mosquito Larvae, Distribution of Abate Powder, Fogging Activities, Facilities, Facilities, Increased Participation Society in Dengue Prevention. It takes a lot of education to the people of Pondok Petir to make people aware of the importance of knowing about DHF. The most effective and efficient prevention of dengue fever to date is the Mosquito Nest Eradication (PSN) activity using $3 M$ Plus, namely: 1) Draining, is cleaning places that are often used as water reservoirs such as bathtubs, water buckets, water reservoirs drinking water, water reservoirs, refrigerators, etc. 2) Closing, namely closing water reservoirs such as drums, jugs, water towers, and so on; and 3) Reusing or recycling used goods that have the potential to become breeding grounds for denguetransmitting mosquitoes.
\end{abstract}

Keywords: DHF, Behavioral Pattern, Dengue Hemorrhagic Fever. 


\section{INTRODUCTION}

Dengue Hemorrhagic Fever (DHF) is a disease caused by the bite of the Aedes Aegypti mosquito infected with one of the four types of dengue virus with clinical manifestations of fever, muscle aches, and/or joint pain accompanied by leukopenia, rash, lymphadenopathy, thrombocytopenia and hemorrhagic diathesis. In dengue hemorrhagic fever, plasma seepage occurs which is characterized by hemoconcentration (increased hematocrit) or fluid accumulation in body cavities ( World Health Organization ). Dengue Hemorrhagic Fever (DHF) is still one of the main public health problems in Indonesia. The number of sufferers and the area of spread of DHF is increasing along with the increase in mobility and population density, especially in tropical and subtropical areas (Kemenkes RI, 2010).

At the beginning of 2019, Dengue Hemorrhagic Fever (DHF) again increased in several areas, even becoming an Extraordinary Event (KLB) status. In January 2019 there were 15,132 DHF sufferers with 145 people dying in 34 provinces. This figure is twice as high as the figure at the end of January 2018 which recorded 6,167 DHF sufferers with 43 people dying. East Java, West Java, and DKI Jakarta are the three provinces that experienced an increase in the number of dengue cases compared to January the previous year. However, the three provinces have not yet determined the status of KLB. Meanwhile, a number of other regions have determined the status of dengue outbreaks, such as Ponorogo, Jombang, Bojonegoro, Sragen, Manado, East Sumba, West Sumba, West Manggarai, Ngada, South Central Timor, Ende, East Manggarai and Kapuas. When designated as a KLB, the local government can mobilize all resources, not only limited to the capabilities of the local Health Office (Rahmi Yuningsih, 2019).

The epidemiology of dengue was reported throughout the nineteenth and early twentieth centuries in America, southern Europe, North Africa, eastern Mediterranean, Asia, and Australia, and on several islands in the Indian Ocean, south and central Pacific, and the Caribbean (WHO, 1999). The first outbreak of dengue in Asia was found in Manila in 1954 and was reported by Quintas. In 1958 there was an outbreak of "Thai" DHF which was found in Bangkok-Thonburi and its surroundings. In 1960 in Singapore, more cases of young adult DHF were found with the results of dengue virus isolation showing types 1 and 2. In 1968, fourteen years after the first outbreak in Manila, DHF was reported for the first time in Indonesia in the form of a DHF outbreak in Jakarta. and Surabaya recorded 58 cases of DHF. In the following year, DHF cases spread every year. Outbreaks of dengue disease occur in most urban areas and some rural areas. Until now, DHF is still a public health problem in Indonesia. Dengue fever is increasing and spreading to all districts in the territory of the Republic of Indonesia every year. In observations for a period of 20 to 25 years since the initial discovery of dengue cases, the number of outbreaks of dengue disease is estimated 
every five years (Soegianto, 2004). The incidence of dengue cases in Indonesia from year to year tends to fluctuate.

The increase in the number of DHF cases is related to individual behavioral factors in implementing PSN (Eradication of Mosquito Nests) and 3M (Draining, Closing, and Burying). Other factors such as the habit of preventing mosquito bites and environmental factors around the house such as stagnant water around the house which is a breeding ground for mosquitoes (Sitinjak K. Diana. Etc. 2015). The World Health Organization (WHO) reports that more than 2.4 billion people out of 7.2 billion (about $40 \%$ of the world's population) are currently infected with the dengue virus and Indonesia still ranks the highest incidence of DHF in Southeast Asia (WHO, 2012). Good and systematic handling is needed to deal with this DHF disease and the participation of the community and health workers is needed to work hand in hand to protect the environment from Dengue Hemorrhagic Fever by monitoring the spread of mosquito larvae and implementing PSN 3M Plus.

One of the infectious diseases that have a high morbidity and mortality rate is Dengue Hemorrhagic Fever (DHF). DHF is caused by a virus Dengue is transmitted through mosquito bites Aedesaegypti and Aedes albopictus (Bustan, 2007: 5; Zulkoni, 2014: 145).

Factors that can affect the increase and spread of dengue cases are host factors, the environment consists of geographical conditions (altitude, rainfall, wind, humidity, and season) and demographic conditions (population density, mobility, community behavior, and socio-economic

residents), and agents (Zulkoni, 2011:149). Factors from the host, agent, and environment influence each other, so that if you want to eradicate this DHF disease, it requires good and balanced control, both from the host, agent, and the environment to control this DHF disease.

The rapid spread of DHF is because the dengue virus is getting easier and more likely to infect humans. In addition, it is also supported by: 1) the increasing number of residents in the city. 2) public attitudes and knowledge about disease prevention are still lacking. The increase in dengue fever in the last 15 years is thought to be caused by several important factors, including 1) unplanned and uncontrolled urbanization and population growth resulting in the dense population living in urban centers tropical climates with poor hygiene conditions, 2) Ineffective control programs against vector mosquitoes, lifestyle changes and worsening of drinking water systems resulting in expansion and increase in the density of the main vector mosquitoes. Another risk factor for DHF transmission is poverty which causes people to not have the ability to provide adequate and healthy housing, drinking water supply, and proper waste disposal.

West Java Province is one of the endemic provinces of DHF in Indonesia. There is a tendency to increase the number of DHF patients from year to year. Until 2007, all districts/cities in West Java had reported dengue outbreaks. 
Preventive behavior factors that should be routinely carried out but are still not considered and ignored include the habit of wearing long clothes, the habit of using mosquito repellent, the habit of hanging clothes in the house, and the lack of community participation with the environment are also factors that can increase the incidence of dengue disease. In addition, a person's immunity factor, the infecting virus strain, history, and age also have an effect.

As a tropical area, Indonesia's conditions support the occurrence of various infectious diseases including dengue fever as an endemic disease. This can be seen from the increasing incidence of DHF in various regions. The role of the media as a messenger for public health services through television, newspapers, and radio is expected to be able to change the attitudes and behavior of mothers in eradicating dengue. However, the Indonesian Ministry of Health who is responsible for information, communication, and mass media must be involved in coordinating the issuance of messages on prevention and eradication of dengue so that it is easy to provide preventive and health promotion efforts to all people in Indonesia.

As well as related to community behavior patterns where behavior patterns are someone's actions or behavior that have been arranged/composed because the process of that behavior is carried out repeatedly, and forms a pattern so that it is carried out every day. If the community and health workers have a pattern of behavior that can prevent the transmission of dengue fever, the incidence of dengue fever in Indonesia will certainly be easier to decrease. And if the opposite is done, the incidence of DHF will certainly continue to increase so that it can cause outbreaks.

This study aims to determine the factors of community behavior patterns that influence the cause of dengue hemorrhagic fever $(D H F)$ in the Pondok Petir village area.

\section{METHODS}

According to data in 2019, Dengue Hemorrhagic Fever (DHF) has increased again in several areas, even becoming an Extraordinary Event (KLB) status. During January 2019 there were 15,132 DHF sufferers with 145 people dying in 34 provinces. This figure is twice as high as the figure at the end of January 2018 which recorded 6,167 DHF sufferers with 43 people dying. East Java, West Java, and DKI Jakarta are the three provinces that experienced an increase in the number of dengue cases compared to the previous year.

This research uses the Simple Random Sampling technique. This study studied the incidence of dengue in children to adults (dependent variable), with respondent characteristics (age, history of dengue disease), counseling (knowledge), attitudes (family attitudes), and behavioral patterns (behavior of health workers, rarely monitoring larvae). mosquitoes, distribution of abate powder, fogging activities), and increasing community participation in dengue prevention (independent variable). To obtain the data, an in-depth interview and document review approach was 
conducted with the community at Pondok Petir. This research was conducted at Pondok Petir, South Tangerang in June 2021.

5 respondents were interviewed in June 2021, sampling was done online via telecommunications. Respondents are the right targets for research. Sampling in this study was selected using the Simple Random Sampling method with the characteristics of the respondents (age, history of dengue disease), counseling (knowledge), attitudes (family attitudes), and behavioral patterns (behavior of health workers, rarely monitoring mosquito larvae, distribution of abate powder, fogging activities). ), and increasing community participation in the prevention of DHF (independent variable).

Data analysis by triangulation of data sources was carried out by in-depth interviews with respondents according to the criteria. While the triangulation method by reviewing documents from journals that are following the title and purpose of this study.

Data validity was done by the triangulation method. To maintain the validated data in this study, triangulation of data sources and method triangulation were used. Triangulation of data sources is carried out by conducting interviews with respondents, while the method of collecting data is by reviewing documents from journals that are following the title and purpose of this study.

\section{RESULTS AND DISCUSSIONS}

Table 1. Results of categories and subcategories

\begin{tabular}{|c|c|c|c|c|c|}
\hline Topic & Meaning Unit & Code & Sub Category & Category & Theme \\
\hline $\begin{array}{l}\text { Do you } \\
\text { often clean the } \\
\text { tub? }\end{array}$ & $\begin{array}{l}\text { 1. } \begin{array}{l}\text { Rarely } \\
\text { cleaned } \\
\text { because they } \\
\text { don't have } \\
\text { much time }\end{array} \\
\text { 2. Not cleaned } \\
\text { because it has } \\
\text { a busy time } \\
\text { 3. Often cleaned } \\
\text { once a week } \\
\text { 4. Rarely cleane } \\
\text { d because of } \\
\text { lazy }\end{array}$ & $\begin{array}{l}\text { Frequency } \\
\text { of cleaning the } \\
\text { bath }\end{array}$ & $\begin{array}{l}\text { 1. Rarely cleaned } \\
\text { 2. Never cleaned } \\
\text { 3. Cleaned } \\
\text { frequently } \\
\text { 4. Rarely cleaned }\end{array}$ & $\begin{array}{l}\text { Behavior } \\
\text { pattern }\end{array}$ & $\begin{array}{l}\text { Behavioral } \\
\text { patterns that } \\
\text { affect DHF }\end{array}$ \\
\hline $\begin{array}{l}\text { Do you use } \\
\text { Abate? }\end{array}$ & $\begin{array}{ll}\text { 1. } & \text { Never } \\
\text { 2. } & \text { Rarely } \\
\text { 3. } & \text { Once a week } \\
\text { 4. } & \text { Once a month }\end{array}$ & $\begin{array}{l}\text { frequency } \\
\text { of using abate }\end{array}$ & $\begin{array}{ll}\text { 1. } & \text { Never } \\
\text { 2. } & \text { Rarely } \\
\text { 3. } & \text { Once a week } \\
\text { 4. } & \text { Once a month }\end{array}$ & $\begin{array}{l}\text { Behavior } \\
\text { pattern }\end{array}$ & $\begin{array}{l}\text { Behavioral } \\
\text { patterns that } \\
\text { affect DHF }\end{array}$ \\
\hline $\begin{array}{l}\text { Are } \\
\text { you fogging? }\end{array}$ & $\begin{array}{ll}\text { 1. } & \text { Never } \\
\text { 2. } & \text { Rarely } \\
\text { 3. } & \text { Once a week } \\
\text { 4. } & \text { Once a month }\end{array}$ & $\begin{array}{l}\text { fogging frequen } \\
\text { cy }\end{array}$ & $\begin{array}{ll}\text { 1. } & \text { Never } \\
\text { 2. } & \text { Rarely } \\
\text { 3. } & \text { Once a week } \\
\text { 4. } & \text { Once a month }\end{array}$ & $\begin{array}{l}\text { Behavior } \\
\text { pattern }\end{array}$ & $\begin{array}{l}\text { Behavioral } \\
\text { patterns that } \\
\text { affect DHF }\end{array}$ \\
\hline $\begin{array}{l}\text { Do you think } \\
\text { fog is } \\
\text { effective in } \\
\text { minimizing } \\
\text { dengue fever? }\end{array}$ & $\begin{array}{ll}\text { 1. } & \text { No need } \\
\text { 2. } & \text { Maybe } \\
\text { 3. } & \text { Effective } \\
\text { 4. } & \text { Do not know }\end{array}$ & $\begin{array}{l}\text { Fogging } \\
\text { effectiveness }\end{array}$ & $\begin{array}{ll}\text { 1. } & \text { Ineffective } \\
\text { 2. } & \text { Ordinary } \\
\text { 3. } & \text { Effective } \\
\text { 4. } & \text { Do not know }\end{array}$ & Knowledge & $\begin{array}{l}\text { Behavioral } \\
\text { patterns that } \\
\text { affect DHF }\end{array}$ \\
\hline
\end{tabular}




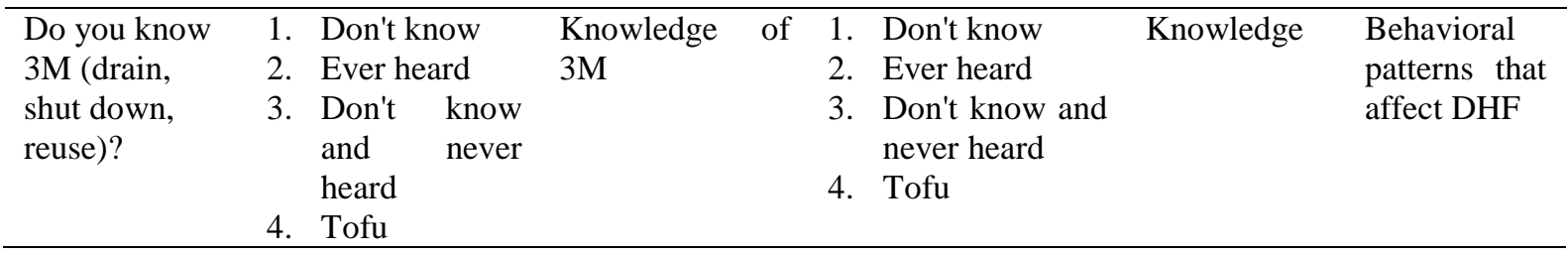

Table 2. Synthesis of code and category data

\begin{tabular}{|c|c|c|c|c|c|c|}
\hline Category & Knowledge & Knowledge & \multicolumn{4}{|c|}{ Behavior } \\
\hline $\begin{array}{l}\text { sub- } \\
\text { category }\end{array}$ & $\begin{array}{l}\text { Behavioral } \\
\text { patterns that } \\
\text { affect DHF }\end{array}$ & $\begin{array}{l}\text { Behavioral } \\
\text { patterns that } \\
\text { affect DHF }\end{array}$ & $\begin{array}{l}\text { Behavioral } \\
\text { patterns that } \\
\text { affect DHF }\end{array}$ & $\begin{array}{l}\text { Behavioral } \\
\text { patterns that } \\
\text { affect DHF }\end{array}$ & $\begin{array}{l}\text { Behavioral } \\
\text { patterns } \\
\text { that affect } \\
\text { DHF }\end{array}$ & $\begin{array}{l}\text { Behavioral } \\
\text { patterns } \\
\text { that affect } \\
\text { DHF }\end{array}$ \\
\hline category & $\begin{array}{l}\text { 1. Don't know } \\
\text { 2. Ever heard } \\
\text { 3. Don't know } \\
\text { and never } \\
\text { heard } \\
\text { 4. Tofu }\end{array}$ & $\begin{array}{l}\text { 1. Ineffective } \\
\text { 2. Ordinary } \\
\text { 3. Effective } \\
\text { 4. Do not } \\
\text { know }\end{array}$ & 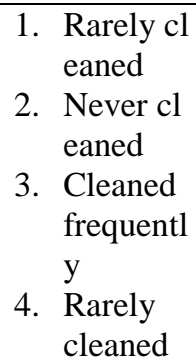 & $\begin{array}{l}\text { 1. Never } \\
\text { 2. Rarely } \\
\text { 3. Once a } \\
\text { week } \\
\text { 4. Once a } \\
\text { month }\end{array}$ & $\begin{array}{l}\text { 1. Never } \\
\text { 2. Rarely } \\
\text { 3. Once a } \\
\text { week } \\
\text { 4. Once a } \\
\text { month }\end{array}$ & $\begin{array}{l}\text { 1. Never } \\
\text { 2. Rarely } \\
\text { 3. Once a } \\
\text { week } \\
\text { 4. Once a } \\
\text { month }\end{array}$ \\
\hline
\end{tabular}

Knowledge

The following are the results of in-depth interviews with respondents related to knowledge, namely:

a. fogging

Fogging is effective to minimize dengue disease

Fogging is not necessary to minimize dengue disease

Fogging is effective to minimize dengue disease

Fogging may be effective to minimize dengue disease

Fogging is effective to minimize dengue disease

b. $3 \mathrm{M}$

I know about $3 M$

I don't know and never heard of $3 M$

I know about $3 M$

I've heard of $3 M$

I know about $3 M$

Behavior Pattern

a. Cleaning the tub 
I rarely clean the tub because I don't have much time

I often clean once a week

I often clean once a week

I often clean once a week

I rarely clean the tub because I don't have much time

b. Using abate

I rarely use abate

I never use abate

I never use abate

I use abate once a week

I once a month use abate

c. Fogging

I rarely use fog

I never use fog

I never use fog

I use fogging once a week

I use fogging once a month

From the results of interviews with the community regarding the knowledge and behavior patterns of DHF, it can be seen that public awareness of the importance of implementing prevention through $3 \mathrm{M}$ is still not comprehensive. From the results of interviews regarding the effectiveness of fogging, there were only three respondents who stated that fogging was effective for prevention, one respondent said it was not effective and another said it might be effective for prevention.

In the question of knowledge about $3 \mathrm{M}$, three respondents know this but two of them do not know about 3M. In the questionnaire regarding behavioral patterns in the sub-category of "cleaning the tub" three respondents often clean the bath with a frequency of once a week. Two respondents stated that they rarely clean the tub because they do not have much time.

The use of abate is carried out by two respondents, one respondent rarely uses abate, one respondent uses abate once a week, and one respondent uses abate once a month. From the results of questions regarding fogging, one respondent stated that they rarely do fog, two of them never do fog, one respondent does fog once a week, and one respondent does fog once a month.

\section{CONCLUSIONS AND SUGGESTIONS}

It takes a lot of education from the people of Pondok Petir to make people aware of the importance of knowing about DHF. The most effective and efficient prevention of dengue fever to date is the Mosquito Nest Eradication (PSN) activity using 3M Plus, namely: 1) Draining, is cleaning places that are often used as water reservoirs such as bathtubs, water buckets, water reservoirs 
drinking water, water reservoirs, refrigerators, etc. 2) Closing, namely closing water reservoirs such as drums, jugs, water towers, and so on; and 3) Reusing or recycling used goods that have the potential to become breeding grounds for dengue-transmitting mosquitoes.

It is recommended that the local health office cooperates with the RT/RW in Pondok Petir to conduct counseling related to DHF and how to prevent it. There is a process of monitoring or monitoring from the relevant health department to evaluate whether the program is effective in reducing the percentage of dengue fever in Pondok Petir.

\section{REFERENCES}

1. Studies, P., Programs, K., Applied, S., \& Health, FI (2018). The relationship between health behavior and the incidence of dengue at the Bantul II Public Health Center, Yogyakarta .

2. Work, W., Pamulang, P., \& Rohim, A. (2017). BASED ON ENVIRONMENTAL FACTORS \& HOST IN .

3. Fever, K., Dengue, B., Di, DHF, \& Balung, D. (2008). Behavioral factors related to the incidence of dengue hemorrhagic fever (DHF) in Balung Lor Village, Balung District, Jember Regency.

4. Epidemiology, J., \& Community, K. (2019). Factors Influencing the Incidence of Dengue Hemorrhagic Fever in Children aged 6-12 Years in Tembalang District. 4 (1), 1-10.

5. Hidayati, L., Hadi, UK, \& Soviana, S. (2017). The Incidence of Dengue Hemorrhagic Fever in Sukabumi City Based on Climatic Condition. 5 (1), 22-28.

6. II, BAB, \& Libraries, T. (nd). 17.18 2.2. 9-23.

7. Payangan, D., Against, D., Prevention, U., Dengue, DB, \& Citrajaya, H. (2016). No Title.

8. Knowledge, C., Java, IW, \& Kalimantan, W. (2016). Community Knowledge and Behavior in Prevention of Dengue Hemorrhagic Fever in West Java and West Kalimantan Provinces. 8 (November 2015), 69-76.

9. No Title. (2015). 1, 42-47.

10. Pekalongan, K., Ade, J., Suryani, I., Galuh, C., Tirto, K., \& Tengah, J. (2019). No Title. 4 (April), 33-40.

11. South, CT (nd). EVALUATION OF DRAINAGE CHANNELS ON SARUA-DRAINAGE CHANNEL EVALUATION ON SARUA-CIPUTAT RAYA ROAD Elma Yulius . 6 (2), 118-130.

12. Society, JK (2016). No Title. 4.

13. Knowledge, C., Java, IW, \& Kalimantan, W. (2016). Community Knowledge and Behavior in Prevention of Dengue Hemorrhagic Fever in West Java and West Kalimantan Provinces. 8 (November 2015), 69-76. 
E-ISSN: 2808-5361 http://e-journal.fkmumj.ac.id/
Proceeding The First Muhammadiyah InternasionalPublic Health and Medicine Conference

14. Dasuki, D., \& Kusnanto, H. (2008). PREVENTION OF HEALTH FEVER IN HOUSEHOLD ROLE OF MASS MEDIA IN MOTHERS' BEHAVIOR TO PREVENT HEMORRHAGIC. 24 (3), $103-110$.

15. Jentik, AB, \& Analysis, S. (2017). ABSTRACT. 7 (2).

16. Yuningsih, R. (2019). 13 community empowerment in overcoming dengue hemorrhagic fever outbreaks.

17. Applied, SS, \& Yulitiana, R. (2017). HEALTH ANALYSIS D-IV STUDY PROGRAM.

18. Pamungkas, G., \& Kurniasari, N. (2019). The Relationship between the Completeness of Health Center Facilities and Infrastructure with Patient Satisfaction at the Melong Asih Health Center, Cimahi City in 2019. 13, 60-69.

19. Influence, A., Service, K., Facilities, AND, Satisfaction, T., \& Puskesmas, P. (nd). Quality Influence Analyst ... 1-26.

20. Meiliyana, L., Damayanti, R., Education, D., Behavior, I., Society, FK, \& Indonesia, U. (2020). COMMUNITY PARTICIPATION IN THE PREVENTION OF DENGUE FEVER DISEASE: A SYSTEMATIC REVIEW. 14 (47), 25-37. https://doi.org/10.36082/qjk.v14i1.102 
Volume I Tahun 2021

November 2021
E-ISSN: 2808-5361

http://e-journal.fkmumj.ac.id/
Proceeding The First Muhammadiyah InternasionalPublic Health and Medicine Conference 